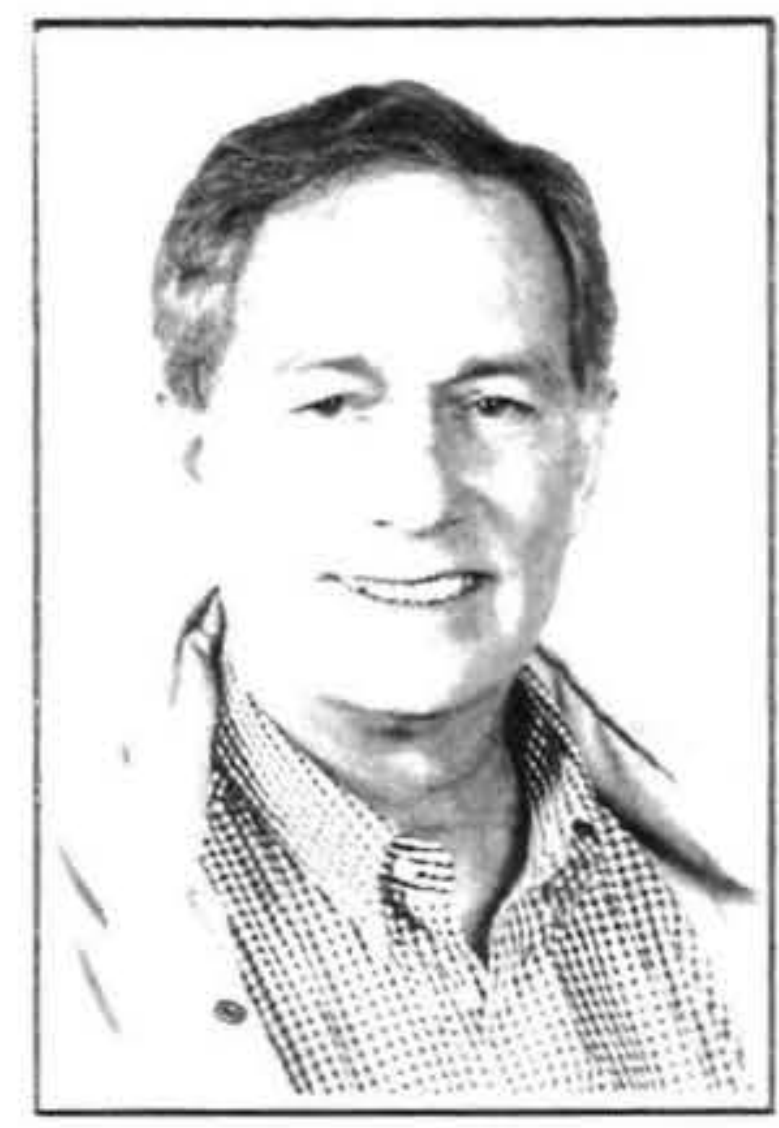

\title{
WORK AND UNEMPLOYMENT IN POST-INDUSTRIAL TIMES
}

\author{
Allan Levett \\ Social Science Consultant
}

\begin{abstract}
In New Zealand, rises and falls in the rate of unemployment over the past twenty years have inevitably produced statements of hope for a return to full employment. It is suggested that the continued simple optimism about full employment has obscured alternative explanations for especially long term unemployment and delayed genuine attempts to make adequate provision for it: provisions that relate to the nature of modern work and give more meaning to the lives of unemployed people. The paper will develop an alternative explanation of unemployment based on an analysis of worldwide changes in the nature of work and show how it applies in New Zealand. The explanation leads to different ways of thinking about unemployment and the wide range of experiences within the unemployed conditions and expands the possibilities for suitable policies. A crucial central ingredient for unemployment policy in postindustrial times is an effective national system of life-long learning. The paper finds that provisionsfor lifelong learning in New Zealand still favour the well-endowed and the well-heeled and are seriously deficient for those whom unemployment hits hardest, creating damaging ripple effects in other aspects of social life. With adequate provisions it is suggested that unemployment can be regarded as a transition in the life course when new kinds of work and new ways of contributing to the community can be explored.
\end{abstract}

This paper is one of synthesis. I intend to bring some of the research on work, unemployment and wider trends, in New Zealand and other countries, to bear on provisions for unemployed people.

I contend that the present arrangements for the unemployed - a mixture of more or less universal economic benefits, plus vocational training for a few - have built-in deficiencies. Evidence suggests that they are too narrow and limiting and do not accomplish what is now required.

Although I wish to make proposals for New Zealand, the setting is the modern world. We can see global trends impacting on work and on state provisions for the unemployed in many countries. At the back of my argument is the notion that the welfare state of the industrial era, which we still use, cannot adequately provide for the demands of post-industrial times.

In order to suggest alternatives it is necessary to consider briefly the state and unemployment, then the nature of modem work itself, in New Zealand and elsewhere: how the organization of work affects economic growth, what the best of it now requires of employees and prospective employees and how changes in work contribute to unemployment. The argument goes beyond these matters because changes in work are having profound effects throughout society. I will consider, third, those social effects that are relevant to education and suggest that educational provisions for unemployed people should be part of a national system of life-long learning. With flexible systems in place that cater equitably for all citizens during the whole of the life course, both employed and unemployed, the society itself will also benefit, socially and economically.

Inevitably such a large canvas can be painted only in broad brush strokes: often with assumptions drawn from limited research data. However I hope that this theoretical framework will enlarge understanding, help define broad directions for policies, and stimulate further research. The objective is to ensure that provisions for the unemployed will benefit both individuals and the larger society.

\section{Political interest in unemployment}

Compared with unemployment during the depression of the 1930s today there are no long dole queues, no angry protest marches and little visible evidence of the high levels of unemployment which we now experience. The modem unemployed are largely quiescent and not easily distinguished from the employed. This is not to say that there are no impacts and no human suffering, just that the effects are harder to distinguish from other social trends.

As a consequence, consistent political interest in, and public sympathy for the unemployed are difficult to sustain. Often there is impatience and inevitably an element of 
blame and even punishment in policies for the unemployed. The policies seem to embody a belief that more effort from the unemployed will help get the economy going again, that the unemployed will themselves create the work that is required. This is not to imply that the unemployed have no obligations. Policies often, implicitly or explicitly put more emphasis on what the unemployed might do and relatively less on the role of employers, employees and other forces in stimulating economic growth, issues I will return to below.

Present policies for the unemployed have little impact on economic performance and the public is often confused and sceptical about political pretensions. In recent elections in Europe voters did not treat unemployment as a serious political issue, despite average rates in the European Union of around $10 \%$ and a total number of officially unemployed persons of 17.2 million people.

In Denmark the comedian, Jacob Hougaard, was elected to the Folketing from the urban district of Aarhus, only the second independent in 80 years. He represents the Party of Consciously Work-Shy Elements which looks forward to the day when unemployment is not a mere $12.5 \%$ but $75 \%$. The 'party' also favours shorter supermarket queues, better weather in Denmark and a tail wind for cyclists. 1

Indeed one can query if the unemployed feature large in the minds of politicians in any country where there are welfare states, except as a matter of state spending or for keeping pressure on wages for the employed. There is also a widespread belief that once the economies 'get going' we will see a return to full employment. In New Zealand even slight dips in the rate of unemployment have produced such optimism. The economic growth in 1994 which at years's end produced a drop in unemployment to $7.5 \%$ has sent some politicians and economists into paroxysms of high hopes. Can we really know what proportion of the paid workforce will be required in the future to produce sufficient goods, services and wealth in the post-industrial society? We know only, and in broad outline, the nature of work in effective economies.

\section{Weakening of the nation state}

In his brilliant recent book 'The Age of Extremes' Eric Hobsbawm argues persuasively that the period 1914 to 1991 has been one in which the world changed more profoundly and more violently than at any other time in human history. 2 It is a book that reminds us of the complexity of the modern condition: that unemployment is but one of the problems we face, and that much of what is happening in New Zealand is part of a world-wide pattern.

The legacy of what Hobsbawm calls the 'Short 20th Century' includes: the enormous growth in population from under 2 billion in 1914 to nearer 6 billion in 1991, despite the huge scale of purposeful killing of people by other human beings (estimated at 187 million since 1914); a much richer world with most people taller, living longer and better educated than their parents, despite homelessness and mass unemployment in rich countries and other countries still desperately poor, a world economy that is vastly more productive and dynamic than ever before, yet the tensions of troubled economies have undermined political systems everywhere. ${ }^{3}$ At centuries end Hobsbawm finds a political and moral malaise and a mood of uneasiness, in which many people live without confidence in the future. In his view it is not that capitalism no longer works but that it has become uncontrollable.

Hobsbawm recognizes that the nation state now lacks sufficient economic power to guarantee the contract between capital, labour and governments that established the welfare systems in the 1930 s and enlarged them in the $1950 \mathrm{~s}$ and $1960 \mathrm{~s}$. As international investments and movements of capital came to greatly exceed the value of trade in goods, governments had relatively less control over capital. Government's could not sustain the welfare states that had emerged. The result is that some form of retrenchment in welfare provisions has occurred in all countries. Furthermore all governments have been concerned to achieve greater private sector economic growth.

In the two crisis decades after 1973 growth slowed or stumbled and instability, unemployment, and poverty reappeared in most of the developed economies, while growth virtually ceased in much of Africa, Latin America and West Asia. At first the problems were regarded as temporary but the Keynesian solutions which had seemed to cure the ills of the 1930s did not produce the desired results and disillusion with state-managed industries and public administration became common.

The ultra-liberal notions tried in the 1980 s had a salutary effect on certain economies, such as in regulated Britain and New Zealand, but economic growth was not accompanied by equivalent growth in employment. At the same time these policies exacerbated the gap between rich and poor which was growing for other reasons, and weakened organized labour as a protecting force. Nor did they address the problem of maintaining social cohesion in the face of fractionating society. In the United States and many European countries, isolated segments of the population unemployed, welfare dependent, poorly educated, many homeless, often with disrupted family patterns, the socalled underclass -provided fertile grounds for political extremism, violence, drug abuse and crime. ${ }^{4}$ By 1990 s it was obvious that neither Keynesiansim nor ultra-liberalism on their own were satisfactory.

The widespread uncertainty, the 'sullen tension that penetrated politics', arose because the transformation of the world economy had changed the nature of work. Hobsbawm focuses on the world-wide loss of jobs, jobs that would never come back: at first in the manufacturing industries but by the 1990s large sections of white collar workers. "These were times when people were likely to lose their bearings." 5 


\section{Changes in Work and Composition of the Work-force 6}

It is not just that fewer people are required in manufacturing and other work. There are substantial changes in the way work is organized. ${ }^{7}$ In mass production people often operated like cogs in a machine. Specialized production and niche marketing require all staff to behave more intelligently and responsively, and to bring problem-solving and communication skills to all parts of the workplace. In the most effective work organizations there is less coercion and more negotiation by managers. The production people have to understand marketing, and vice versa. The result is fewer layers of management and thus flatter organizations. It is a change from static flexibility (the ability of a firm to adjust its operations to shifts in the market) to dynamic flexibility (the ability to increase productivity steadily through improvements in the production process and innovations in the products). ${ }^{8}$

Most major kinds of work are changing in the same general direction. For example, clerical work too requires more conceptual ability and more active participation. 9 The pattern is similar all over the developed world. ${ }^{10}$ The new technology enables large organizations to operate in decentralized ways, stimulating business to operate across national boundaries on a global scale. Firms can more readily source supplies and labour where price advantages exist. Technology and conceptual knowledge affects all work, lowering the cost of production, transportation and communication, and forcing down prices of commodities. Movement of capital greatly exceeds the movement of goods, adding to the importance of knowledge-based services in the world's work-force.

Reich suggests three main types of paid work emerging in post-industrial societies: symbolic-analytic services, inperson services and routine services. ${ }^{11}$ It is not a classification for one society: each type has a distinctive competitive position in the world economy. This relatively crude classification is useful for high-lighting tendencies.

The routine service jobs, unless they can be upgraded to include symbolic-analytic features, are being transferred to low wage countries. Thus their numbers, value and pay are declining rapidly in advanced countries. Most inperson service jobs are not as transferable because of the person-to-person element, but they are subject to international pressures to be competitive. So long as they remain simple jobs, wages can be held down: in the US the pay is declining, "somewhat more slowly and unevenly". ${ }^{2}$ The symbolic-analytic jobs cover a wide range of work and involve conceptualizing and problem-solving abilities, communication and negotiating skills. Most of all they require originality of thought. It is symbolic-analytic work for which pay is increasing, world wide. As Reich says:

The global economy is tightly linking our citizens to the citizens of other nations - linkages as strong as, if not stronger than, the economic connections binding us to one another within our borders. Our well-educated prob- lem-solvers grow wealthier; our poorly educated routine workers become poorer. ${ }^{13}$

Apparently the three functional types cover three out of four American jobs. Not included are farmers, miners and other extractors. 14

Symbolic-analytic work is dependent on a high level of generic education. There is evidence to show that countries with the highest educational levels in the work-force, plus policies and facilities in place to ensure constant upskilling, have been best able to take advantage of new technologies. ${ }^{15}$ Furthermore, symbolic-analytic work can grow and routine work decline without substantial growth in employment.

In addition to changes in the nature of work there are a number of other features associated with postindustrialism. These include the increased participation of women, and increases in employment volatility: more job-sharing, part-time work, contract work and job changing. These are largely responses to the need for flexibility of work-force organization. People are more often moving in and out of work, as jobs disappear, and learning new skills, as work itself is continually changing. The consequence, as Block points out, is an end to the 'linear life course' built around the 'one-career one-marriage imperative'. 16

Lifelong educational opportunities are required for the entire work-force in postindustrial times, opportunities that require conceptual development as well as up-skilling. Furthermore, at a national level, the more such educated abilities are widespread and available in a population, the more quickly new ideas and new technologies will diffuse through that population, providing national comparative advantage. ${ }^{17}$ Cohen and Zysman make a similar point:

The mix of available skills shapes the evolution of technology. If we want technologies that support a highwage, high value-added economy we have to ensure the education and skills to make that possible. ${ }^{18}$

\section{The New Zealand situation}

To compete successfully businesses have to increase productivity and lower costs. They could apply technology, which means raising skills and shedding staff; or they could reduce operations by dropping staff, lowering wages, and using part-time or contingent (temporary) workers. There is evidence that both options are being taken in New Zealand.

The high-skilled, highly paid jobs in professional, technical, managerial and administrative occupations grew from 15 percent of the employed work-force in 1971 to 25 percent in 1991; and the lower skilled, lower paid jobs in production, operator and labouring occupations declined from 37 percent to 23 percent. ${ }^{19}$ Furthermore, there are leading edge New Zealand companies using research, applying technology, introducing participative methods of 
management and upskilling staff, especially in the export sector. 20 The meat industry is an example. The workforce has halved while productivity has doubled. The large labour-intensive freezing works are being replaced by smallermarket-driven meat plants with multi-skilled workforces emphasizing quality cuts for particular markets. There is purposeful co-ordination of the entire process from animals to markets. Research is being applied at every stage in the process. 21

At the same time there is evidence that the low-skilled option is also being taken in New Zealand. Many firms are reluctant to use technology and train staff. Their managers are under-educated for current market technological requirements and unprepared to manage staff in participative ways. New Zealand firms are low users of $R$ and $D$, and are reluctant to explore Asian markets and to recognize and reward Asia skills among their staff members. ${ }^{22}$ Between 1971 and 1991 unemployment increased from 2 percent to 10 percent, part-time work grew from 5 percent to 18 percent, and the self-employed expanded from 13 percent of the paid workforce to 20 percent. 23 The latter includes a range from highly paid consultants to modestly paid copy typists, cleaners and contract gardeners. Furthermore, "the disposable income gap between the top 20 percent of wage and salary earners and all other wage and salary earners has widened over the $1980 \mathrm{~s}^{n} .24$

As unemployment has continued to rise in New Zealand and elsewhere in the developed world, the incidence of long-term unemployment has increased. There is a growing number of people who remain out of work most of the time. As the skills gap between them and the employed continues to widen, their chances of obtaining work decline and the economic and social costs of unemployment increase. 25 Without appropriate skills development, simple economic recovery cannot reduce longterm unemployment in the post-industrial societies. And, as we have seen, without appropriate skills development, managers are unlikely to make the kinds of decisions about the handling of staff, the use of technology and research, and the search for new markets off-shore, that will create maximum benefit - including maximum employment - in the post-industrial societies. We can no longer achieve sustainable economic growth with an under-educated workforce; and we can no longer create work for under-educated unemployed people.

\section{Condition of the unemployed}

What is happening to the unemployed under the present conditions of relatively benign neglect? The adequacy of income support varies across modern welfare states? There is surprisingly little systematic nationwide information about the unemployed for any post-industrial society. ${ }^{26}$

Yet a modest study in Dunedin indicates broadly similar patterns among the unemployed to those found by a large thorough research project in the Netherlands. 27 Under somewhat different welfare state arrangements in both countries there is a wide range of responses to the unemployed condition.

There was seemingly less variability among those who remained unemployed at the height of the industrial era prior to the existence of income support. According to the classic study carried out in Marienthal, Austria, in 1933, where three-quarters of the breadwinners lost their jobs when a factory closed, just $23 \%$ of the unemployed remained resilient, tried to make ends meet and kept on looking for jobs. A further $70 \%$ became resigned, developed fatalistic attitudes including a contracted sense of time. For $7 \%$ of the families, the situation was intolerable: families split up, there was despair, apathy and resort to alcohol and crime. The researchers found considerable malnutrition among the children and one third in poor health. 28

The modern experience, where income support exists, is different. Among the 1403 unemployed people surveyed in Dunedin in 1989, one sixth of all unemployed in the city, a majority actually saw more friends and experienced better health. One quarter said they were in, or seeking, tertiary education and $66 \%$ said they were 'coping OK'. A further $12 \%$, mostly young people, reported 'actually enjoying the lifestyle of being out of work'. Just $15 \%$, mostly over 40 years of age, said they were not coping, and 6 percent reported serious health problems. 29

At the same time in New Zealand, we know that unemployment affects the young more than the old, Maori and Pacific Islanders much more than other ethnic groups, the unqualified more than the qualified, and certain parts of the country more than others. ${ }^{30}$ (This bare recounting of some facts is not to imply that there is no misery or other serious effects arising from unemployment.) While unemployment affects some groups more than others it should not be forgotten that all groups and all occupations are affected to some degree.

We have more detailed information from a study in the Netherlands in 1987 which was used to take a comparative look at long-term unemployment and urban poverty. A sample was drawn from $36 \%$ of the total unemployed in that country, in the age range 23 to 50 , people who had been out of work for more than two years. The generalities about the relationship between unemployment on the one hand and age, ethnicity, qualifications and regions on the other, cited above for New Zealand, are similar in all countries. Also, as unemployment grew in the Netherlands, and elsewhere in Europe, particularly from the mid1970 s, the proportion of the long-term unemployed grew more sharply. The study focused on the consequences of long-term unemployment, how the individuals perceived and experienced their situation in connection with the possibilities for their return to the official labour market. ${ }^{31}$

I will quote selectively from this study, concentrating on the range of ways in which the people experienced unemployment. The use of time varied widely. Whereas $57 \%$ of 
the respondents said they were sometimes bored, the remainder said they were seldom or never bored. Some of the latter, a quarter of the total, found the advantages of unemployment more important than the disadvantages or thought they were of equal importance. Many felt that a job would 'cramp their style.' 32 However most were active with hobbies, odd jobs, volunteer work and clubs, etc.

One-third rarely or never looked for a job, while $20 \%$ did so at least weekly. About $45 \%$ "remained dutiful and tenaciously continued to look for a job, even in the face of repeated rejection", while the others had reduced or completely stopped their job-seeking efforts. Among these, about a quarter were resigned while the others "had found other activities to give meaning to their lives". ${ }^{33}$ The writers described the work ethic as 'utilitarian':

a job did not mean just an abstract duty ... however they would not accept just any job.... welfare liberated them somewhat from the necessity to work and allowed them to claim new rights; the right to do decent and useful work, to fulfil themselves and to develop on the job, to develop social contacts, and to participate in the consumption ofgoods and services provided by modern society. 34

It should be noted that "the Dutch unemployed are under less pressure to accept whatever job they can get at any cost", than the American, and that the Netherlands differs from a country like Sweden, where there had been a more active labour market policy. 35

Dependence on the state was perceived by the long-term unemployed in a wide range of ways. The authors distinguished what they called 'two ideal types': (1) those who felt very dependent on the benefit and were bothered by the feeling. They tended to view the benefit as something they should be grateful for and not as something they had a right to; and (2) those who were not bothered in the least by feelings of dependence. It is in this category that the researchers found people who had managed to manipulate the welfare system or who worked 'off the books'. 36

The researchers identified six broad types of unemployed respondents in terms of their behaviour and expectations vis a vis the labour market.

conformists (36\%): Continued to strive for goals of paid employment, applied for jobs, some sought training, even though prospects of work were slight. Made only proper use of social security system. Mainly male, over 40 , low to average educational level.

ritualists (9\%): Had given up hope of finding work, etc, but clung to society's rules and customs. Mainly older male, unemployed for long periods, low educational level. High proportion of foreign descent people.

retreatists (25\%): No longer aspired to job and high consumption, saw few prospects and did not try. Re- signed. Mainly older male, foreign, low educational level.

enterprising (10\%): Aimed for a job and high consumption but tried to reach it by informal methods. Instrumental view of work. Mainly young male, single, long time out of work but had worked. Average to high education, few foreign.

calculating (9\%): Made little use of formal channels to attain higher consumption and no compunction about improper use of social security system. Did not aim for work. Mainly female, young, well-educated. Few foreign.

autonomous (10\%): Attached little importance to goals of work and consumption. Wanted to do own thing, barely tried to find work, adjusted needs to limited finance. Neither undertook informal work nor made improper use of benefit system. Low to average education, wide age range, many female, few foreign.

The latter two categories are the strictly 'modern' unemployed which can exist only within the contemporary social security system. Well-educated single people more often had the social skills that enabled them to approach the benefit system in a calculating way or to make good use of the informal economy, thus were more likely to exhibit calculating or enterprising behaviour. The older, poorly educated and foreign had much less opportunity for these activities and retreatism was 'an understandable reaction'. The authors also found that different kinds of social and cultural relations within neighbourhoods were associated with each of the six types of behaviour and feelings about being unemployed. 37

The striking feature of this analysis of the long-term unemployed is that only $19 \%$, the enterprising and the calculating, exhibit entrepreneurial behaviour that could be useful 'to get the economy going again'; but these are also the most likely to make improper use of the social security system. The benefits provide a certain standard of living for the others, but little of it is used in economically relevant ways. Few bother to maintain work skills and even fewer try to acquire new skills. The benefit system is thus dependency-creating without being stimulating or encouraging self-reliance, enterprise, and the acquisition of skills. Furthermore, as noted earlier, the system often carries stigma and sometimes appears to promote false expectations of providing a solution to unemployment.

If the benefit system has large loop-holes, and has become dependency-sustaining without adding to economic capabilities, where should we look for solutions? One obvious linkage is education.

Education for employment, unemployment and the enlargement of life

The educational system which emerged in all industrial 
societies was hierarchical and consisted of: university education for the few required to staff the professions and provide much of the leadership; technical training for another small proportion; on the job training for the remaining adults; and a system of compulsory school designed to select students for the various tiers of post-school education. Various other adult education programmes were developed, more in some societies than in others. These narrow hierarchical arrangements are dysfunctional for postindustrial societies, both economically and socially.

As it has turned out those countries which developed the broadest approach, in particular those with a middle stratum that reached higher levels of attainment and which had industry-based education that continued on beyond schooling, such as Germany, Sweden and Japan, were best able to take advantage of innovative technologies and to respond to new market opportunities in the $1980 \mathrm{~s}$. ${ }^{38}$ Education in postindustrial society is required to equip people for new forms of work at many stages during the life course, not hierarchical but accessible to all. Although the case cannot be made here, lifelong education is required not only for an effective economy, but much more widely to provide skills for living, as and when they are sought.

Growth of the New Zealand economy will be enhanced by educational programmes for specific groups, such as managers and farmers, where there is evidence to suggest that under-education is restricting development. ${ }^{39}$ The educational reforms have created a structure, the New Zealand qualifications framework which is admirably suited to the credentialling of flexible lifelong learning, such as is required for these forms of up-skilling or re-tooling by mature workers. But the institutions have not caught up. The universities especially, still present their programmes in inconvenient packages, essentially designed in the early twentieth century, mainly to young adults in the top third of the ability range. The recent report by the Taskforce on Employment continued this emphasis. 40 In post-industrial societies appropriate educational programmes are required by the employed and the unemployed throughout the life course for maintaining and developing knowledge and skills that are useful for jobs and for living.

\section{Conclusion}

Unemployment could be regarded as a time for maintaining skills or acquiring new knowledge so that individuals are prepared to take advantage of any expansion of the work-force that occurs, and to play a full role in the community. Education for living and education for work need not be separated. In New Zealand two main developments are necessary before this can occur: suitable educational programmes that reflect changing demand; and a linkage between these programmes and the benefit systems so that unemployment is not only a condition of dependency on income support.

\section{Future research}

1. Social Ties: A network approach to the study of unem- ployment has been found to be an important supplement to economic job search theories in overseas research. To be useful, such work requires identification of specific local settings. The New Zealand experience will be distinctive.

Social ties can be important to finding a new job and maintaining good health. They are a form of social capital. On the other hand, it appears that the most disadvantaged have fewer connections and also social ties of lesser social worth: they have lower volumes of social capital.

What is the relationship between social ties and unemployment in New Zealand? Where are the most effective social ties located, effective for health, friendships, knowledge of jobs and educational opportunities? Are educational centres an important locus of relevant social ties for unemployed people? What kinds of educational centres are most suitable? What are the consequences for jobs of different kinds of social ties?

\section{Longterm unemployment and job-seeking behaviour:} What are the stages of job-seeking behaviour through which different kinds of unemployed people go, as unemployment is prolonged? To what extent are they affected by the 'creaming'behaviour of agencies, ie always offering the most skilled the first opportunities?

\section{Longterm unemployment and education-seeking behav-} iour? What are the past educational experiences of unemployed people in relation to current interests in education? To what extent is re-tooling or up-skilling on the agenda? How accessible and suitable are local educational facilities?

4. Managers and Up-skilling. What kinds of re-tooling and up-skilling do different kinds of managers consider as they encounter problems of expansion or retrenchment? How appropriate are current educational facilities?

\section{Notes}

1 Financial Times (23 September, 1994)

2 Eric Hobsbawm, 1994.

3 Hobsbawm, op. cit. chapter 1.

4 Christopher Jencks and Paul E. Peterson (1991)

5 Hobsbawm, op.cit. ch 2.

6 In this section and the next I draw extensively from Allan

Levett and Tom Dwyer, (1994)

7 M.Best (1990), F.Block (1990)

8 Block (1990), op.cit. : 195 .

9 Block (1990) : 103.

10 Best op.cit.(1990); M.Sharp (ed) (1986); L.Thurow (1991).

11 R.B. Reich (1992): 174.

12 ibid, 205.

13 ibid, 320.

14 ibid, 180.

15 A.Levett, P.Callister and ILivingstone : chapter 2.

16 Fred Block (1990) : 11.

17 M.Sharp (1986) : 281.

18 S. Cohen and J. Zysman (1987) : 7

19 P. Callister (1993). 
D. Gilbertson and R.M.Knight (1992)

21 New Zealand Meat Producers Board (1992) : 21

22 Levett, et al, op cit, ch 8.

23 Department of Statistics (1993)

24 ibid, 133.

25 D. Grimmond (1993)

26 Chapter 1 in G. Engbersen, K. Schuyt, J. Timmer and

F. Van Waarden (1993)

27 G.Ng and T.Beer (1990) op. cit.

28 Marie Jahoda (1982)

29 G.Ng and T.Beer op. cit.

30 Prime Ministerial Task Force on Employment (1994)

31 Engbersen, et al, op.cit. chapters 1 and 2.

32 ibid, 93.

33 ibid, 113.

34 ibid, 121.

35 ibid, ch 6 .

36 ibid, 148.

37 ibid, ch 8.

38 Sharp op cit; C. Freeman (1987)

39 A. Levett, et al, op.cit., chapter 7.

40 Prime Ministerial Task Force on Employment (1994)

\section{References}

Best, M. 1990, The New Competition: Institutions of IndustrialRe-structuring,Cambridge, MA: Harvard University Press.

Block, F. 1990, Postindustrial Possibilities, Berkeley: University of California Press.

Callister, P. 1993, Tomorrow's Skills - 1993 Update, Wellington: The Careers Service (Quest Rapuara).

Cohen, S. and J.Zysman, 1987, Manufacturing Matters: The Myth of the Postindustrial Economy, New York: Basic Books.

Department of Statistics, 1993, New Zealand Social Trends: Work, Wellington.

Engbersen, G., K.Schuyt, J.Timmer, and F. Van Waarden, 1993, Cultures of Unemployment: A Comparative Look at Long-term Unemployment and Urban Poverty, Boulder: Westview Press.

Financial Times, 23 September, 1994, Welfare dilemma for Nordic social democracie"; 7 October, 1994, Employment fails to excite German voter".

Freeman, C. 1987, Technology Policy and Economic Performance:Lessonsfrom Japan, London: Pinter.

Gilbertson, D. amd Knight, R.M., 1992, Innovation and Management in New Zealand: A Casebook, Palmerston North: Dunmore Press.

Grimmond, D., 1993, Labour Force Dynamics in New Zealand, Wellington: New Zealand Institute for Economic Research, Monograph 60.

Hobsbawm, E. 1994, The Age of Extremes: the Short
Twentieth Centure, 1914-1991, London: Michael Joseph.

Jahoda, M. 1982, Employment and Unemployment: A Social-Psychological Analysis, Cambridge University Press.

Jahoda, M., P.Lazarsfield and H. Zeisal, 1972, Marienthal: The Sociography of and Unemployed Community, London: Tavistock Publications.

Jencks, C. and P. Peterson (eds) 1991,The Urban Underclass, Washington: The Brookings Institute.

Levett, A., P.Callister and I. Livingstone, forthcoming, The Re-Framing of Lifelong Learning, Wellington: The New Zealand Qualifications Authority.

Levett, A. and T.Dwyer, 1994, Re-thinking employment and unemployment, New Zealand Geographer, 50, (1): 40-45.

New Zealand Meat Producers Board, 1992, The business of New Zealand meat, The New Zealand Meat Producer, Wellington, 21.

Ng, G. and T. Beer, 1990, Pride and prejudice: a matter of facts. Unemployment in Dunedin, Dunedin City Council and Dunedin Copuncil of Trade Unions.

Prime Ministerial Task Force on Employment, 1994, Employment: the Issues, and Proposalsfor Action: Addressing New Zealand's Biggest Challenge, Wellington: The Task Force.

Reich, R. 1992, The Work of Nations, New York: Vintage Books.

Sharp, M. (ed) 1986, Europe and the New Technologies, Ithaca: Cornell University Press.

Teekens, R. and B. van Praag, (eds), 1990, Analyzing Poverty in the European Community, Luxembourg: Eurostat New Special Edition.

Thurow, L. 1991, Head to Head: The Coming Battle Among Japan, Europe and America, New York: Morrow.

\section{Author}

Allan Levett is a Social Science Consultant, 12 Winston St, Wellington. 